\title{
Isolation and Characterization of Antibiotic Producing Actinomycetes from Mud Nest of Wasps
}

\author{
Md. Fazlul Haque ${ }^{1^{*}}$, Sabina Sultana1, Moni Krishno Mohanta ${ }^{1}$, \\ Md. Ariful Hasan ${ }^{1}$, Arnaba Saha Chaity ${ }^{1}$, Shamsunnahar ${ }^{1}$ \\ and Israt Jahan Khan Chowdhury ${ }^{1}$
}

${ }^{1}$ Genetics and Molecular Biology Laboratory, Department of Zoology, University of Rajshahi, Rajshahi-6205, Bangladesh.

Authors' contributions

This work was carried out in collaboration among all authors. Author MFH designed the study, performed the statistical analysis and wrote the protocol and the first draft of the manuscript. Authors MFH, Shamsunnahar and IJKC did the experimental works of the study. Authors SS, MKM, MAH and ASC managed the literature searches and edited the manuscript. All authors read and approved the final manuscript.

Article Information

\author{
DOI: $10.9734 / A R R B / 2019 / v 34 i 530166$ \\ Editor(s): \\ (1) Paola Angelini, University of Perugia, Perugia, Italy. \\ Reviewers: \\ (2) Umoru Mohammed Askira, University of Maiduguri, Nigeria. \\ (3) Kamal E. M. Elkahlout, Islamic University of Gaza, Palestine.
} (1) Faniomi Ayodele Samuel, Federal University of Technology, Akure, Nigeria. Complete Peer review History: http://www.sdiarticle4.com/review-history/54599

Original Research Article

Received 13 December 2019

Accepted 21 February 2020

Published 04 March 2020

\begin{abstract}
The recent increase in antibiotic resistance demands the discovery of novel antibiotics. Hence, this project was designed to explore novel antibiotic producing Actinomycetes from mud nest of wasps. For this, 9 types of active mud nests of wasp available in Rajshahi, Bangladesh were collected. For each nest, nest material was aseptically homogenized with a $1 \mathrm{X}$ saline solution and then diluted homogenate was plated in Actinomycetes Isolation Agar medium to isolate Actinomycetes. Total 27 purified cultures of bacteria were isolated from 9 collected mud nests of wasp. To collect the extract of mud nest, homogenate was filtered and centrifuged. Then, the extracts were assessed for their efficacy to inhibit bacterial growth with disc diffusion method. However, only extract of nest number 9 (N9) showed antimicrobial efficacy against tested bacteria, E. coli. Then antimicrobial efficacy of the 27 isolates was assessed using an agar cross-streak method and disc diffusion method. It was found that among the 27 isolates; only the isolate N9C2 was able to inhibit the growth of studied bacteria, E. coli. Then, 16S rDNA was isolated, amplified and sequenced from the isolate N9C2 for
\end{abstract}


its identification. According to NCBI blast, the highest similarity of sequence (99\%) of $16 \mathrm{~S}$ rDNA of the isolate N9C2 was shown to that of Streptomyces coelescens strain AS 4.1594. Then, the isolate $\mathrm{N} 9 \mathrm{C} 2$ was characterized. It was found that the isolate was a gram positive filamentous bacterium. It was found that the isolate $\mathrm{N} 9 \mathrm{C} 2$ was resistant to Amoxicillin, Ampicillin and Cephalexin while it was sensitive to Tetracycline, Erythromycin and Ciprofloxacin. It was also found that the isolate $\mathrm{N} 9 \mathrm{C} 2$ can grow optimally at $\mathrm{pH} 7$ and at $37^{\circ} \mathrm{C}$. Finally, it can be concluded that mud nests of wasp is a vital source of antibiotic producing Actinomycetes such as Streptomyces coelescens strain AS 4.1594.

Keywords: Actinomycetes; antibiotic; mud nest; wasp.

\section{INTRODUCTION}

Discovery of antibiotics more than 100 years ago enable us to fight against life-threatening diseases caused by different types of pathogen such as viruses, bacteria, fungi and protozoa [1]. Uses of antibiotics are now familiar in world either in poor or developed countries. It is really difficult to find out a person who has no taken antibiotic at least once to treat infectious diseases or other injuries. However, emergence of multidrug or extremely drug resistance pathogens is knocking to end the golden age of antibiotics started in 1050. Thus, many almost eradicated diseases such as tuberculosis are threatening us to return in novel form even in developed countries [2,3]. The research on exploration of a novel antibiotic is very time consuming and costly [1]. Hence, research activity on this essential area has been reduced significantly because of less chance of making profit by pharmaceutical companies. Collective effect of this factor and emergence of antibiotic resistant pathogens may lead to a frightening condition in the near future as in 100 years ago for infectious diseases. Therefore, discovery of new antibiotic is essential. Natural products and their derivatives which are produced by different types of insects are known as the key source for clinically used antibiotic [4-6]. Moreover, most of antibiotics which are clinically available now are invented from Actinomycetes or fungi. Therefore, the recent prevalent of multidrug resistant pathogens has created a new interest in recognizing uncharacterized habitats to isolate Actinomycetes that produce novel antimicrobial compound. Insect nest associates are subsequently being inspected as a probable source of such novel antibiotics $[7,8]$. In spite of the potentiality of insect nest materials for chemical or microbial novelty, research on this field is comparatively few. Hence, this research was designed to explore novel antibiotic producing Actinomycetes from mud nest of wasps available in Rajshahi, Bangladesh.

\section{MATERIALS AND METHODS}

\subsection{Nest Collection}

Mature, active nests of wasps which were usually built on wall of houses were selected for collection. In absence of wasp, mud nests were separated from wall with sterile forceps and scalpel which were then aseptically collected in polyethylene bag and stored at $4^{\circ} \mathrm{C}$ in refrigerator for further use in research work. Nests were used for identification of wasp genus. Nests were considered to be active if live wasp residents were found to patrol the nests on the date of collection. In the laboratory, nest materials were aseptically separated by removing all eggs, larvae, pupae and active individuals from the nest. Nests which were parasitized by brood parasitoids [9] were separated by visual inspection and finally discarded from the study. All nests were collected from Rajshahi city, Bangladesh.

\subsection{Microorganism Isolation}

For each nest, nest material (including paper, pedicel, meconium) was aseptically mechanically homogenized with forceps, and placed in a conical tube with a $1 \mathrm{X}$ saline solution. Tubes were vortexed and the resulting homogenate was diluted in the same solvent and plated in Actinomycete Isolation Agar medium (Himedia, India) with following composition for $1000 \mathrm{ml}$ of medium: Sodium caseinate $2 \mathrm{gm}$, L-Asparagine $0.1 \mathrm{gm}$, Sodium propionate $4 \mathrm{gm}$, Dipotassium phosphate $0.5 \mathrm{gm}$, Magnesium sulphate $0.1 \mathrm{gm}$, Ferrous sulphate $0.001 \mathrm{gm}$, Agar $15 \mathrm{gm}$ and Glycerol $5 \mathrm{ml}$ [10]. Plates were incubated at ambient room temperature $\left(28^{\circ} \mathrm{C}\right)$ and bacterial colonies were streaked for purification as they grew (continuously after 72 h). Colonies exhibiting morphologies indicative of Actinomycetes were selected for further purification. 


\subsection{Antimicrobial Production Assay}

The ability of the Actinomycete isolates to inhibit bacterial growth was assessed using an agar cross-streak method and disc diffusion method. For agar cross-streak method, the selected isolates were inoculated onto LuriaBertani (LB) (Himedia, India) agar plates by continuous streak on one side ( $3 \mathrm{~cm}$ width). It was found during pure culture preparation, the selected colony of Actinomycetes was able to grow sufficiently after 3 days of incubation which was also comparable to finding of other studies [11]. Hence, the plates were incubated at $30^{\circ} \mathrm{C}$ for 3 days. Then, Grampositive bacterium, Bacillus cereus and Gramnegative bacterium, Escherichia coli were streaked perpendicular to the antagonistic Actinomycete on the agar medium. The plates were incubated at $37^{\circ} \mathrm{C}$ for $24 \mathrm{~h}$. The microbial inhibitions were observed by determining the diameter of the inhibition zones [12].

For disc diffusion method, the selected isolate was inoculated into $100 \mathrm{ml}$ of LB (Himedia, India) broth and incubated at $30^{\circ} \mathrm{C}$ in a shaker at 200 rpm for seven days. After incubation, the broth was collected which was then filtered through whatman (No.1) filter paper. The collected filtrates were then centrifuged at $5000 \mathrm{rpm}$ for 10 min. Then, the supernatant of the centrifuged filtrates was transported aseptically into a screw capped bottles and stored at $4^{\circ} \mathrm{C}$ for further experiments. Similarly, nest of wasp was crushed and refined with pestle and mortar. Then, 10 gram of refined nest material was mixed with $10 \mathrm{ml}$ of sterilized water. Mixture was centrifuged at $5000 \mathrm{rpm}$ for $10 \mathrm{~min}$. The supernatant was transferred aseptically into a screw capped bottles and stored at $4^{\circ} \mathrm{C}$ for further assay. For each test, $100 \mathrm{ml}$ LB(Himedia, India) broth in each flask was inoculated with few cells of Escherichia coli and Bacillus cereus separately and incubated at $37^{\circ} \mathrm{C}$ for 24 hours in rotary shaker rotate at $120 \mathrm{rpm}$. Then, $1 \mathrm{ml}$ of incubated broth culture was spread homogenously on a nutrient agar plate with a sterile spreader. The inoculated plate was airdried for few minutes. Sterile filter paperdiscs were soaked with $30 \mu \mathrm{l}$ of $100 \%$ concentration of supernatants collected from liquid culture and nest materials (preserved in a screw capped bottles as mentioned above). Then these discs wereplaced on inoculated nutrient agar plates. An antibiotic disc of Kanamycin (KAN) was used as control in each plate. Then, the plates were incubated at $37^{\circ} \mathrm{C}$ for 24 hours. After incubation, clear zones indicated inhibition of growth of the microorganisms. The zones around the discs were measured and recorded. The all experiments for antimicrobial production assay were replicated for 3 times independently.

\subsection{Identification of Antibiotic Producing Bacteria with 16S rDNA Sequencing}

Genomic DNA was extracted from antimicrobial agent producing bacterium using CTAB method [13]. A universal PCR primer was used for amplification of $16 \mathrm{~S}$ rDNA fragments. The protocol as previously described [14]. Briefly, the PCR amplification was achieved by Swift ${ }^{\mathrm{TM}}$ Minipro Thermal Cycler originated from Singapore (Model: SWT-MIP-0.2-2). The following program was used for PCR amplification: Denaturation was performed at $95^{\circ} \mathrm{C}$ for 5 minutes which was then followed by 40 cycles of 40 seconds of denaturing at same temperature, 60 seconds of annealing at $65^{\circ} \mathrm{C}$ and 2 minutes of elongation at $72^{\circ} \mathrm{C}$ with a final extension at $72^{\circ} \mathrm{C}$ for 10 minutes. Then, the PCR products were subjected to gel electrophoresis (1\% agarose), stained with ethidium bromide and visualized on a UV transilluminator for the existence of about 1500 bp PCR products. PCR amplified 16s rDNA of the selected isolate was sent for automated sequencing (Applied Biosystem 3130). The sequence generated from automated sequencing of PCR amplified DNA was analyzed through NCBI BLAST (http://www.ncbi.nlm.nih.gov) program to find out possible similar organism through alignment of homologous sequences. Finally, the isolate was identified based on alignment of partial sequence of $16 \mathrm{~S}$ rDNA with the existing sequences available in the database.

\subsection{Antibiotic Sensitivity Test}

Antibiotic Sensitivity test was achieved by disc diffusion method as previously described [2,15] Briefly, the isolate N9C2 collected from nest of wasp was grown in nutrient broth that were placed in a shaker at $35^{\circ} \mathrm{C}$ temperature and 120 rpm for 3 days. After 3 days of incubation, $1 \mathrm{ml}$ of the culture was transferred and gently spread on the nutrient agar plate and air dried. Then, antibiotic disks were placed on the respective plates and incubated for 3 days at $35^{\circ} \mathrm{C}$.

\subsection{Determination of Optimum Growth Conditions}

To determine the optimum $\mathrm{pH}$ of bacterial growth, culture medium was adjusted to $\mathrm{pH} 6.5$, 
$7.0,7.5$ and 8.0 respectively. Then, each $50 \mathrm{~mL}$ of culture media were inoculated with $1 \mathrm{~mL}$ of culture of isolated bacteria. The growths of bacteria at different condition were determined at different time intervals ( 4 hourly) by measuring optical density at $660 \mathrm{~nm}$ with photoelectric colorimeter.

For determination of optimum temperatures, culture medium was adjusted to $\mathrm{pH}$ 7.0. Then, medium was distributed in four different conical flasks, $50 \mathrm{~mL}$ in each flask. Each $50 \mathrm{~mL}$ of culture media were inoculated with $1 \mathrm{~mL}$ of culture of isolated bacteria. Then, inoculated media were incubated at $25^{\circ} \mathrm{C}, 30^{\circ} \mathrm{C}, 35^{\circ} \mathrm{C}$ and $40^{\circ} \mathrm{C}$ temperature in incubator. The growths of bacteria at different condition were determined at different time intervals ( 4 hourly) by measuring optical density at $660 \mathrm{~nm}$ with photoelectric colorimeter.

\section{RESULTS AND DISCUSSION}

\subsection{Muddy Nests of Wasp Available in Rajshahi, Bangladesh}

Nine types of nest of wasp (N1, N2, N3, N4, N5, N6, N7, N8 and N9) were collected from different location in Rajshahi, Bangladesh (Fig. 1). Collected nests were diverse in shape, structure and size. Nest N1 was a cluster of short vase like structure which was made of mud. Nest N2 was a single long vase like muddy structure. Nest N3 and N6 were collection of few pipes like muddy structure. Nest N4 was long irregular shaped muddy structure with several opening. Nest N5 was short multi-chambered muddy structure. Nest N7 was long single chambered nest surrounded with multiple shields like structure. Nest N8 was collection of few capsules like short muddy chambers while N9 was collection of small vase like structure which was made of some resin like sticky material mixed with mud, sand particles and sticky material (Fig. 1).

In this study, diversity of nests of wasp was found in shape, size and structure which was reported to be related to different taxa of wasps [16]. It is established from the other reports that strengths of defense against pathogen vary among taxa of different wasp. In addition, these differences in defense are strongly related to ranks of social complexity. Altogether, the phylogenetic and antimicrobial data acclaimed that the antimicrobial agents production might have first appeared in solitary wasps as a response to environmental pathogen, more specifically soil-borne pathogens. Burrowing wasps, exposed to soil-borne pathogens, may have developed broad-scale antimicrobial defenses in response. These may have evolved into robust antimicrobial agents in the social lineages [17].

\subsection{Bacterial Colonies Isolated from Collected Nests of Wasp}

Colonies which exhibited morphologies similar to Actinomycetes were selected for further purification. Total 27 colonies were selected for purification which were tagged with code number according to serial of collection and number of the nest, viz. N1C1, N1C2, N1C3, N2C1, N2C2, $\mathrm{N} 3 \mathrm{C} 1, \mathrm{~N} 3 \mathrm{C} 2, \mathrm{~N} 3 \mathrm{C} 3, \mathrm{~N} 4 \mathrm{C} 1, \mathrm{~N} 4 \mathrm{C} 2, \mathrm{~N} 4 \mathrm{C} 3, \mathrm{~N} 5 \mathrm{C} 1$, $\mathrm{N} 5 \mathrm{C} 2, \mathrm{~N} 5 \mathrm{C} 3, \mathrm{~N} 5 \mathrm{C} 4, \mathrm{~N} 6 \mathrm{C} 1, \mathrm{~N} 6 \mathrm{C} 2, \mathrm{~N} 6 \mathrm{C} 3, \mathrm{~N} 7 \mathrm{C} 1$, $\mathrm{N} 7 \mathrm{C} 2, \mathrm{~N} 8 \mathrm{C} 1, \mathrm{~N} 8 \mathrm{C} 2, \mathrm{~N} 8 \mathrm{C} 3, \mathrm{~N} 9 \mathrm{C} 1, \mathrm{~N} 9 \mathrm{C} 2, \mathrm{~N} 9 \mathrm{C} 3$ and N9C4. All the isolated colonies were large, irregular in margin and whitish in colour like fungus. After purification of collected bacterial colonies by repeated streaking, the bacterial isolates were preserved at $4^{\circ} \mathrm{C}$ for further study.

\subsection{Antimicrobial Efficacy of Extract of Nests of Wasp}

The disc diffusion method was used to test the antimicrobial efficacy of nest extract against $E$. coli and Bacillus cereus bacteria. The result of this experiment revealed that extract of nest N9 was only able to yield a moderate zone of inhibition around the disc indicating that extract contained antimicrobial agent to inhibit the growth of E. coli.

In this study, the most of the extract of nest of wasps were unable to inhibit the growth of tested bacteria. Unviability of active compound in nest may be because of construction of mud nest above-ground by solitary species where there is less risk of disease. Otherwise, individual species may have developed specific compounds to combat niche pathogens which are ineffective against tested bacteria [17].

\subsection{Antimicrobial Efficacy of Bacterial Isolates Collected from Nests of Wasp}

Total 27 isolates were collected from nine different nests of wasp. The efficacies of these bacterial isolates were assessed with agar crossstreak and disc diffusion method. It was found that antimicrobial compound produced by the 
isolate $\mathrm{N} 9 \mathrm{C} 2$ only was able to inhibit the growth of the tested gram-negative bacteria ( $E$. coli.) remarkably (Fig. 3). But, the isolate N9C2 failed to inhibit the growth of the tested gram-positive bacteria (Bacillus cereus). However, no antimicrobial compound was produced by remaining 26 isolates against tested bacteria or their production was insignificant (Fig. 3). The result of this test was similar to that of agar cross-streak method. However, zone of inhibition produced by the isolate N9C2 was comparative lower than that produced by Control antibiotic Kanamycin. It might be resulted from lower concentration of antimicrobial agents in supernatant produced by the isolate $\mathrm{N} 9 \mathrm{C} 2$ or from their lower efficacy as compared with Kanamycin.

The isolate N9C2 was capable of producing antibiotic to inhibit the growth of gram-negative $E$. coli bacterium used in this study. Though, it is not clear if this activity arose from one or multiple antimicrobial compounds. Streptomyces spp. are able to produce over 100,000 different antibiotics [18], with some strains generating multiple antimicrobials [19]. This is true even under in vivo conditions, where a cocktail of antimicrobials is expected to assist in nest hygiene [20]. Moreover, this study revealed that most of Actinomycetes isolated from mud nest of wasps was unable to show antimicrobial activity against tested bacteria. In contrary, a study reported that more than $50 \%$ of Streptomyces isolates sequestered from the stingless-bee Tetragonisca angustula was able to show antimicrobial activity against Gram-positive bacteria [21].

\subsection{Identification of Bacterial Isolate N9C2}

The isolate N9C2 was selected for 16S rDNA sequence based identification. The sequence submitted to $\mathrm{NCBI}$ revealed that the highest similarity of sequence $(99 \%)$ of 16 S rDNA of the isolate $\mathrm{N} 9 \mathrm{C} 2$ was shown to that of Streptomyces coelescens strain AS 4.1594. Thus, the sequence analysis indicated that the isolate N9C2 was Streptomyces coelescens strain AS 4.1594 or member of same cluster. Similar results were revealed by other studies. For example, the 30 sequenced actinomycetes isolated from these nests belong to the two most bioactively-rich actinomycete families: Streptomycetaceae and Micromonosporaceae [22], including the three genera, Streptomyces, Micromonospora and Actinoplanes. While Streptomyces, is common soil microbes [23,24].
The strain N9C2 was isolated from mud nest of wasp belong to the genus Streptomyces, reliable with similar studies investigating materials associated with nest of insects [25]. This includes those studies linking to leaf-cutter ants [26,27], wood boring beetles [28,29] honey and stingless bees [30], solitary bees [31], digger wasps [32], mud dauber wasps [33] and termites [34]. Furthermore, a study by Ruddick and Williams [35], proposes that spores of Streptomyces spp. were associated with the cuticle of many arthropods [35]. Similarly, another study revealed that Streptomyces sp. were associated with the larva of Sceliphron madraspatanum, a type of the mud dauber wasps [25]. Therefore, it is not surprising that Streptomyces are often found in nest material.

\subsection{Antibiotic Sensitivity Pattern of Bacterial Isolate N9C2}

Study of antibiotic sensitivity pattern is vital to maintain pure culture of a bacterial isolate as well as to take a decision for using it safely in any environmental application. The patterns of antibiotic sensitivity of bacterial isolate N9C2 to 8 different antibiotics was tested by disk diffusion method using nutrient agar medium. After incubation overnight at $35^{\circ} \mathrm{C}$, the diameter of inhibition zone was measured.It was found that the isolate $\mathrm{N} 9 \mathrm{C} 2$ was resistant to 3 antibiotics viz. Amoxicillin, Ampicillin and Cephalexin while it was sensitive to 3 other antibiotics viz Tetracycline, Erythromycin and Ciprofloxacin. However, the isolate showed intermediate sensitive to Kanamycin and Neomycin (Table 1). The antibiotic sensitivity pattern of the isolate N9C2 was comparable to that of Streptomyces $\mathrm{sp}$. isolated from laterite soil in another study [36].

Table 1. Antibiotic sensitivity pattern of bacterial isolate $\mathrm{N} 9 \mathrm{C} 2$

\begin{tabular}{lll}
\hline $\begin{array}{l}\text { Name of } \\
\text { antibiotic }\end{array}$ & $\begin{array}{l}\text { Zone of } \\
\text { inhibition }\end{array}$ & Comment \\
\hline Tetracycline & $20 \mathrm{~mm}$ & $\mathrm{~S}$ \\
Amoxicillin & No zone & $\mathrm{R}$ \\
Erythromycin & $26 \mathrm{~mm}$ & $\mathrm{~S}$ \\
Kanamycin & $15 \mathrm{~mm}$ & $\mathrm{I}$ \\
Ampicillin & No zone & $\mathrm{R}$ \\
Neomycin & $15 \mathrm{~mm}$ & $\mathrm{I}$ \\
Ciprofloxacin & $30 \mathrm{~mm}$ & $\mathrm{~S}$ \\
Cephalexin & No zone & $\mathrm{R}$ \\
\hline
\end{tabular}

$S=$ Sensitive, $R=$ Resistant, I= Intermediate 


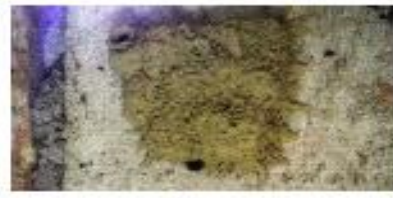

N1

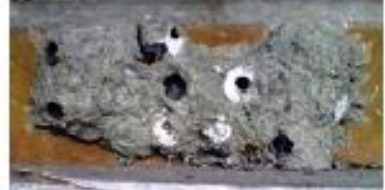

N4

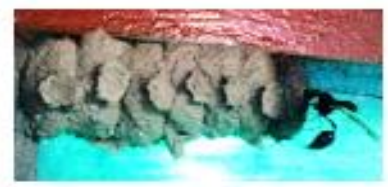

N7

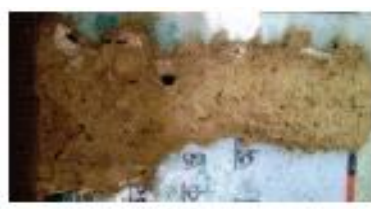

N2

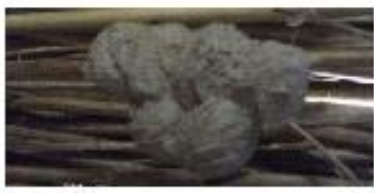

N5

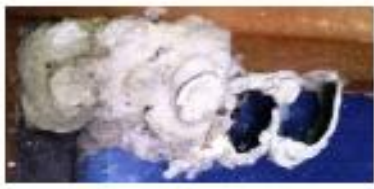

N8

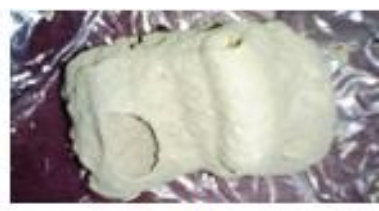

N3

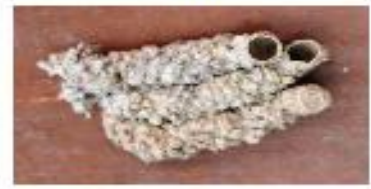

N6

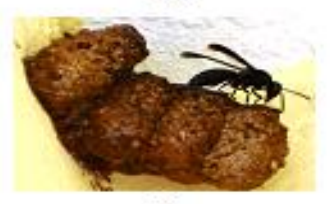

N9

Fig. 1. Nests of wasp available in Rajshahi, Bangladesh

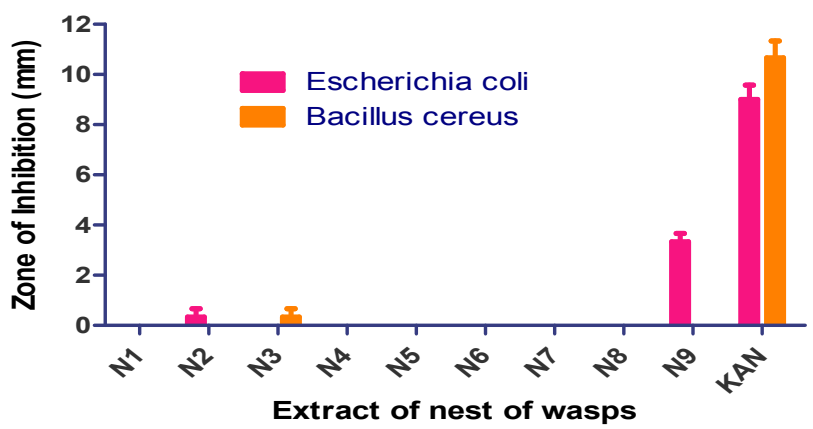

Fig. 2. Antimicrobial efficacy of extract of nest of wasps assessed with disc diffusion method against $E$. coli and $B$. cereus bacteria. Data are mean+SEM from three independent experiments. Antibiotic Kanamycin (KAN) was used as control

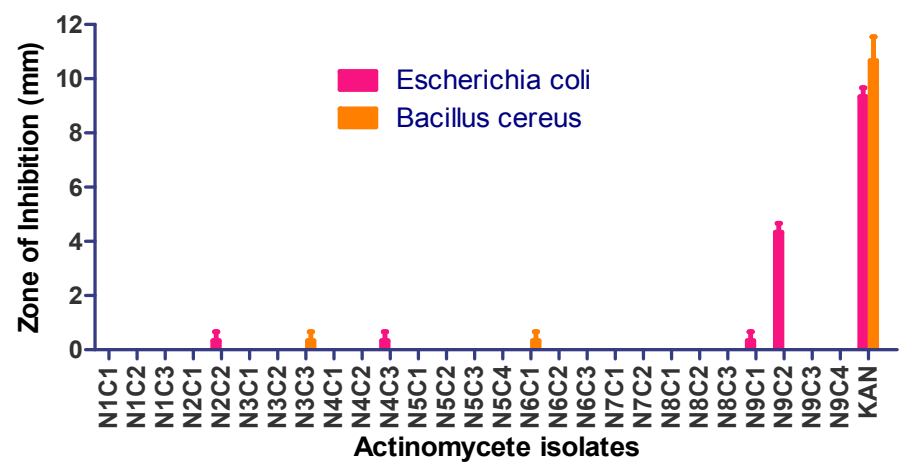

Fig. 3. Antimicrobial efficacy of the compound produced by Actinomycete isolates assessed with disc diffusion method against $E$. coli and $B$. cereus bacteria. Data are mean+SEM from three independent experiments. Antibiotic Kanamycin (KAN) was used as control 


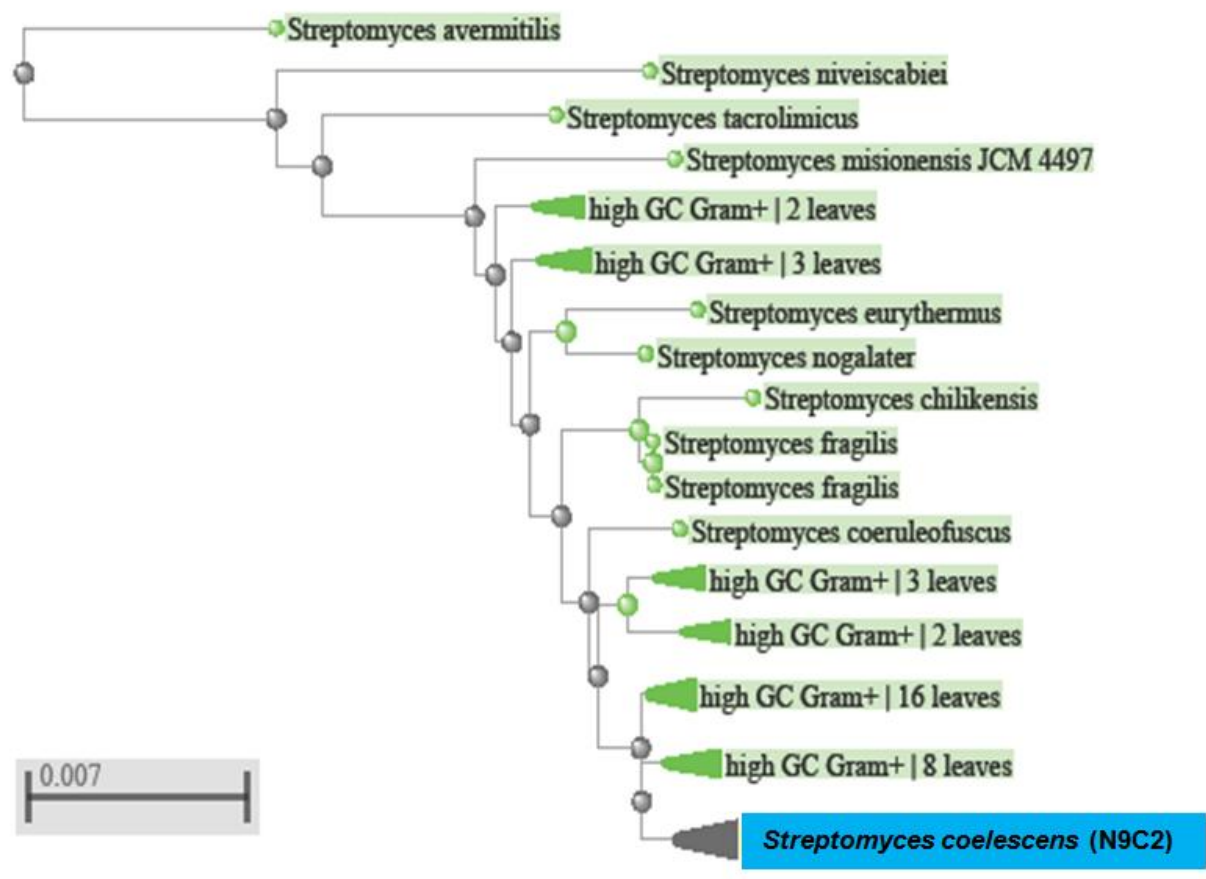

Fig. 4. Unrooted phylogenetic tree showing the genetic relationship between the isolate N9C2 collected from Nest N9 of wasp and reference 16S rRNA sequences from the GenBank based on partial 16S ribosomal RNA gene sequences

\subsection{Optimum Temperature for Growth of Bacterial Isolate N9C2}

Optimum temperature for growth of bacterial isolate $\mathrm{N} 9 \mathrm{C} 2$ was determined at $\mathrm{pH} 7$ in nutrient broth medium. The optimum temperature for growth of the isolate $\mathrm{N} 9 \mathrm{C} 2$ was $37^{\circ} \mathrm{C}$ (Fig. 5). The maximum growth rate of the isolate $\mathrm{N} 9 \mathrm{C} 2$ (OD 1.3) was observed at $35^{\circ} \mathrm{C}$ at 32 hours while the minimum growth rate (OD 1.1) was observed at $28^{\circ} \mathrm{C}$ and $33^{\circ} \mathrm{C}$ at that time (Fig. 5).

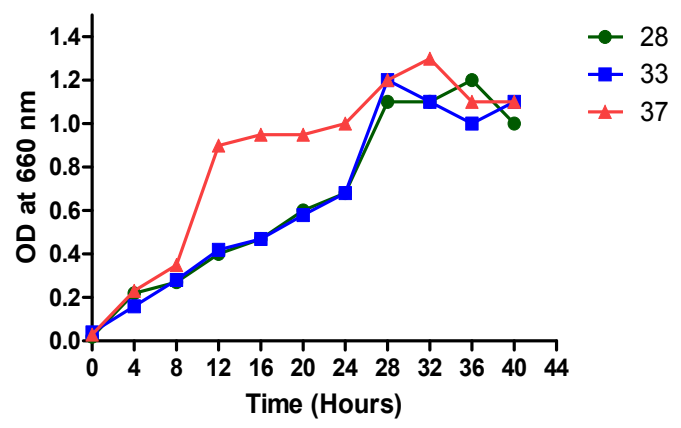

Fig. 5. Optimum temperatures for growth of bacterial isolate $\mathrm{N} 9 \mathrm{C} 2$

\subsection{Optimum pH for Growth of Bacterial Isolate N9C2}

Optimum $\mathrm{pH}$ for growth of bacterial isolate $\mathrm{N} 9 \mathrm{C} 2$ was determined at $37^{\circ} \mathrm{C}$ temperature in liquid broth medium at $\mathrm{pH} 6, \mathrm{pH} 7$ and $\mathrm{pH} 8$. As shown in Fig. 6, the isolate $\mathrm{N} 9 \mathrm{C} 2$ exhibited maximum growth (OD 1.5) at $\mathrm{pH} 7$ after 40 hours of incubation while the minimum growth (OD 0.97) was observed at $\mathrm{pH} 6$ after that time of incubation (Fig. 6).

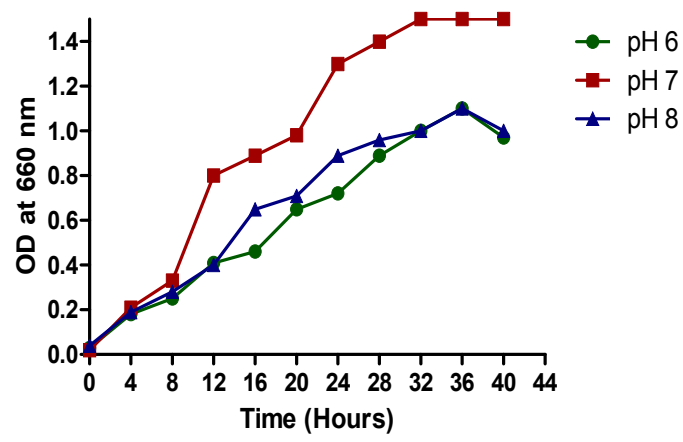

Fig. 6. Optimum pH for growth of bacterial isolates N9C2 


\section{CONCLUSION}

In this study, the isolate N9C2 which was identified as Streptomyces coelescens strain AS 4.1594 can produce antimicrobial compound to inhibit the growth of studied gram-negative bacteria. However, the compound responsible for inhibition of growth was not separated from other compounds produced by the isolate $\mathrm{N} 9 \mathrm{C} 2$. Hence, future studies should be focused on separation and characterization of antimicrobial agent produced by the isolate $\mathrm{N} 9 \mathrm{C} 2$ in order to determine if there was any novel chemistry in the observed antimicrobial defense. By further studies on the complete diversity of the microbial flora associated with these wasps, it will be possible to better comprehend how these wasps maintain hygiene of nests as well as what microbes may control their fitness.

\section{ACKNOWLEDGEMENT}

The authors are grateful to the Rajshahi University research grant programme, University of Rajshahi, Bangladesh for providing fund for this project.

\section{COMPETING INTERESTS}

Authors have declared that no competing interests exist.

\section{REFERENCES}

1. Bode HB. Insects: True pioneers in anti-infective therapy and what we can learn from them. Angewandte Chemie International Edition. 2009; 48(35):6394-6.

2. Mohanta MK, Saha AK, Haque MF, Mahua SA, Hasan MA. Status of antibiotic sensitivity pattern of clinically isolated bacteria collected from Rajshahi City, Bangladesh. Univ J Zool Rajshahi Univ. 2015;34:1-5.

3. Haque MF, Sultana S, Palit S, Mohanta MK, Mahfuz I. Emergence of multidrug resistant Escherichia coli as a common causative agent in urinary tract infection in Bangladesh. Univ J Zool Rajshahi Univ. 2018;37:8-13.

4. Newman DJ, Cragg GM. Natural products as sources of new drugs over the last 25 years $\perp$. Journal of Natural Products. 2007;70(3):461-77.
5. Piel J. Metabolites from symbiotic bacteria. Natural Product Reports. 2004;21(4):51938.

6. Piel J. A polyketide synthase-peptide synthetase gene cluster from an uncultured bacterial symbiont of Paederus beetles. Proceedings of the National Academy of Sciences. 2002;99(22):140027.

7. Zakalyukina YV, Birykov MV, Lukianov DA, Shiriaev DI, Komarova ES, Skvortsov DA, et al. Nybomycin-producing streptomyces isolated from carpenter ant camponotus vagus. Biochimie. 2019;160:93-9.

8. Xie S, Lan Y, Sun C, Shao Y. Insect microbial symbionts as a novel source for biotechnology. World Journal of Microbiology and Biotechnology. 2019; 35(2):25.

9. Madden $A$, Davis $M$, Starks $P$. First detailed report of brood parasitoidism in the invasive population of the paper wasp polistes dominulus (Hymenoptera, Vespidae) in North America. Insectes Sociaux. 2010;57(3):257-60.

10. Eaton AD. CLS, Greenberg AW. Standard methods for the examination of water and wastewater. 21 ed. Washington, D.C.: APHA; 2005.

11. Daigle F, Lerat S, Bucca G, Sanssouci É, Smith CP, Malouin F, et al. A terD domain-encoding gene (SCO2368) is involved in calcium homeostasis and participates in calcium regulation of a DosR-like regulon in streptomyces coelicolor. Journal of Bacteriology. 2015;197(5):913-23.

12. Lemos ML, Toranzo AE, Barja JL. Antibiotic activity of epiphytic bacteria isolated from intertidal seaweeds. Microbial Ecology. 1985;11(2):149-63.

13. Smith G, Socransky S, Smith C. Rapid method for the purification of DNA from subgingival microorganisms. Oral Microbiology and Immunology. 1989; 4(1):47-51.

14. Saha AK, Sultana N, Mohanta MK, Mandal A, Haque MF. Identification and characterization of azo dye decolourizing bacterial strains, alcaligenes faecalis E5. $\mathrm{Cd}$ and $\mathrm{A}$. faecalis Fal. 3 isolated from textile effluents. American Scientific Research Journal for Engineering, Technology and Sciences (ASRJETS). 2017;31(1):163-75. 
15. Saha A, Haque M, Karmaker S, Mohanta M. Antibacterial effects of some antiseptics and disinfectants. Journal of Life and Earth Science. 2009;3(4):19-21.

16. Subathra D, Amrita K, Nitin J, Jemimah N, Mohana S. Screening of actinomycetes isolated from soil samples for antibacterial and antioxidant activity. International Journal of Pharmacy and Pharmaceutical Sciences. 2013;5(4):483-9.

17. Hoggard SJ, Wilson PD, Beattie AJ, Stow AJ. Social complexity and nesting habits are factors in the evolution of antimicrobial defences in wasps. PLoS One. 2011;6(7):e21763.

18. Watve MG, Tickoo R, Jog MM, Bhole BD. How many antibiotics are produced by the genus Streptomyces? Archives of microbiology. 2001;176(5):386-90.

19. Seipke RF, Kaltenpoth M, Hutchings MI. Streptomyces as symbionts: An emerging and widespread theme? FEMS microbiology reviews. 2012;36(4):86276.

20. Kroiss J, Kaltenpoth M, Schneider B, Schwinger M-G, Hertweck C, Maddula RK, et al. Symbiotic streptomycetes provide antibiotic combination prophylaxis for wasp offspring. Nature Chemical Biology. 2010;6(4):261-3.

21. Cambronero-Heinrichs JC, MatarritaCarranza B, Murillo-Cruz C, ArayaValverde E, Chavarría M, Pinto-Tomás AA. Phylogenetic analyses of antibioticproducing Streptomyces $\mathrm{sp}$. isolates obtained from the stingless-bee Tetragonisca angustula (Apidae: Meliponini). Microbiology. 2019;165(3): 292-301.

22. Berdy J. Bioactive microbial metabolites. The Journal of Antibiotics. 2005;58(1):126.

23. Lazzarini A, Cavaletti L, Toppo G, Marinelli F. Rare genera of actinomycetes as potential producers of new antibiotics. Antonie van Leeuwenhoek. 2000;78(3): 399-405.

24. El-Tarabily KA, Sivasithamparam K. Nonstreptomycete actinomycetes as biocontrol agents of soil-borne fungal plant pathogens and as plant growth promoters. Soil Biology and Biochemistry. 2006; 38(7):1505-20.

25. Song $\mathrm{Y}-\mathrm{J}$, Zheng $\mathrm{H}-\mathrm{B}$, Peng $\mathrm{A}-\mathrm{H}$, Ma J-H, Lu D-D, Li $X$, et al. Strepantibins A-C: Hexokinase II Inhibitors from a mud dauber wasp associated Streptomyces sp. Journal of Natural Products. 2019; 82(5):1114-9.

26. Haeder S, Wirth R, Herz H, Spiteller D. Candicidin-producing Streptomyces support leaf-cutting ants to protect their fungus garden against the pathogenic fungus escovopsis. Proceedings of the National Academy of Sciences. 2009; 106(12):4742-6.

27. Zucchi TD, Guidolin AS, Cônsoli FL. Isolation and characterization of actinobacteria ectosymbionts from acromyrmex subterraneus brunneus (Hymenoptera, Formicidae). Microbiological Research. 2011;166(1):68-76.

28. Hulcr J, Adams AS, Raffa K, Hofstetter RW, Klepzig KD, Currie CR. Presence and diversity of Streptomyces in dendroctonus and sympatric bark beetle galleries across North America. Microbial Ecology. 2011; 61(4):759-68.

29. Grubbs KJ, Biedermann PH, Suen G, Adams SM, Moeller JA, Klassen JL, et al. Genome sequence of Streptomyces griseus strain XylebKG-1, an ambrosia beetle-associated actinomycete. Journal of Bacteriology. 2011;193(11):2890-1.

30. Promnuan Y, Kudo T, Chantawannakul P. Actinomycetes isolated from beehives in Thailand. World Journal of Microbiology and Biotechnology. 2009;25(9):1685-9.

31. Inglis GD, Sigler L, Goette MS. Aerobic microorganisms associated with alfalfa leafcutter bees (Megachile rotundata). Microbial Ecology. 1993;26(2):125-43.

32. Kaltenpoth M, Goettler W, Dale C, Stubblefield JW, Herzner G, RoeserMueller K, et al. 'Candidatus Streptomyces philanthi', an endosymbiotic streptomycete in the antennae of Philanthus digger wasps. International Journal of Systematic and Evolutionary Microbiology. 2006; 56(6):1403-11.

33. Kumar V, Bharti A, Gupta VK, Gusain O, Bisht GS. Actinomycetes from solitary wasp mud nest and swallow bird mud nest: Isolation and screening for their antibacterial activity. World Journal of Microbiology and Biotechnology. 2012; 28(3):871-80.

34. Visser AA, Nobre T, Currie CR, Aanen DK, Poulsen M. Exploring the potential for Actinobacteria as defensive symbionts in fungus-growing termites. Microbial Ecology. 2012;63(4):975-85. 
35. Ruddick S, Williams S. Studies on the ecology of actinomycetes in soil V. Some factors influencing the dispersal and adsorption of spores in soil. Soil Biology and Biochemistry. 1972;4(1):93IN7101100IN10103.
36. Kavitha A, Prabhakar P, Vijayalakshmi M, Venkateswarlu Y. Purification and biological evaluation of the metabolites produced by Streptomyces sp. TKVL_333. Research in Microbiology. 2010;161(5):335-45.

(c) 2019 Haque et al.; This is an Open Access article distributed under the terms of the Creative Commons Attribution License (http://creativecommons.org/licenses/by/4.0), which permits unrestricted use, distribution, and reproduction in any medium, provided the original work is properly cited.

Peer-review history:

The peer review history for this paper can be accessed here: http://www.sdiarticle4.com/review-history/54599 